\title{
Upwelling-downwelling sequences in the generation of red tides in a coastal upwelling system
}

\author{
G. H. Tilstone, F. G. Figueiras, F. Fraga \\ Instituto de Investigacións Mariñas, Eduardo Cabello 6, CSIC, E-36208 Vigo, Spain
}

\begin{abstract}
Differences in temporal and spatial hydrographic conditions, water circulation patterns derived from temperature-salinity properties, phytoplankton community composition and distribution were studied in 4 Ría systems (flooded tectonic valleys) in Galicia, NW Spain, from 18 to 21 September 1986. The Rías are affected by upwelling cycles which introduce nutrient-rich Eastern North Atlantic Water (ENAW). During upwelling relaxation periods, the Rías are prone to red tide outbreaks, especially during autumn. In the northern most Ría (Muros), after an upwelling event on 18 September followed by a weak downwelling, a low chlorophyll a (chl a) maximum occurred over the shelf which corresponded to the distribution of a large dinoflagellate/red tide species community identified by principal component analysis (PCA) and cluster analysis of species. This community was identified in all of the other Rias studied, but at different locations. With stronger downwelling on 21 September in the Ría de Vigo, Ría water and the chl a maximum were confined to the Ría interior, which corresponded to a shift in the large dinoflagellate/red tide community. The chl a maximum in all Rias was predominantly due to Heterosigma carterae. The increase in Gymnodinium catenatum cell numbers, from the northern to the southern Rias, corresponded to stronger downwelling events. It is proposed that upwelling-downwelling sequences, enhanced by the presence of inlets and embayments acting as catchment concentration zones, are important mechanisms for generating red tide blooms in coastal upwelling systems.
\end{abstract}

KEY WORDS: Red tides - Upwelling-downwelling cycles · Galician coast - Rías Baixas

\section{INTRODUCTION}

The increase in world incidents of paralytic shellfish poisoning (PSP) and diarrhetic shellfish poisoning (DSP), and the damage to aquaculture, appear to be due to a higher frequency of toxic red tides (Smayda 1990). The general conditions reported for red tide formation include eutrophication, upwelling, physical oceanographic events, pollution and climate (Blasco 1977. Margalef et al. 1979, Cullen et al. 1982, Steidinger 1983, Wyatt \& Reguera 1989, Chen \& Gu 1993, Figueiras \& Ríos 1993, Fraga \& Bakun 1993, Honjo 1993, Moita 1993). The stability of the water column and duration of the seasonal thermocline are important factors in influencing the spatial and temporal formation of red tide assemblages (Pingree et al. 1976, Figueiras \& Ríos 1993). Normally during late summer and after upwelling events, there is a mixing of the water column and nutrient enrichment of the photic zone, both of which favour diatom growth near the coast. Dinoflagellates increase over the shelf in more stratified and nutrient-poor water. With a change in wind direction, a downwelling event disrupts the diatom bloom, and if nutrient levels remain high in the nutricline, red tide organisms take advantage of the enriched environment (Figueiras \& Fraga 1990, Fraga et al. 1992).

The Rias Baixas, situated off the northwestern coast of Spain (Fig. 1), are flooded tectonic valleys which function as positive estuaries (Fraga 1981, Estrada 1984) and enhance the effect of coastal upwelling and downwelling through current bathymetry interactions (Blanton et al. 1984). A strong atmospheric pressure gradient (Fraga \& Bakun 1993) and equatorward winds along the coast (Castro et al. 1994) cause the upwelling of colder, nutrient-rich subsurface water between April and August (Wooster et al. 1976, Fraga 1981, McClain et al. 1986). During the rest of the year, 
south winds prevail which favour downwelling. After the upwelling season in September, followed by stable conditions, the Rías are prone to red tide outbreaks (Margalef 1956, Fraga et al. 1988, 1990, Figueiras \& Pazos 1991, Prego 1992, Figueiras et al. 1994).

Biological and hydrographical data were collected from transects in all of the Rías of Galicia during the Galicia IX cruise, from 4 September to 3 October 1986. It was found that normal conditions in the Ría de Vigo on 4 September corresponded to a light upwelling event (Fraga \& Prego 1989), which did not distort the nutricline, and that the PSP agent Gymnodinium catenatum appeared at the mouth of the Ría de Vigo in low cell numbers (Figueiras \& Pazos 1991). Rain from 18 to 21 September coincided with a change in wind direction from north to south on 19 September, which altered the flow of coastal surface water by opposing the outflow of Ría surface water. This resulted in a downwelling event at the mouth of the Ría and concentrated $G$. catenatum in the interior of the Ría. On 3 October, the re-establishment of positive circulation, a renewal of slight upwelling and some stratification favoured the blooming of this species, culminating in concentrations of more than $10^{6}$ cells $1^{-1}$ (Figueiras \& Pazos 1991). What remains unknown is, firstly, the mechanism of evolution of this red tide community within the 4 Rías Baixas, and secondly, more specifically, whether the downwelling event introduced $G$. catenatum from outside the Ría, or whether it had started to grow in the interior of the Ría, moved to its mouth during outflow, and was then re-introduced as a consequence of downwelling.

This paper thus presents a spatial and temporal evolution of the phytoplankton communities, hydrographic conditions and water circulation patterns in all of the Rías Baixas before the red tide event, starting with phytoplankton assemblages and distributions in the Ría de Muros on 18 September and ending in a more advanced distribution on 21 September in the Ría de Vigo.

\section{MATERIALS AND METHODS}

During the Galicia IX cruise, on board the RV 'García del Cid', samples were collected from 9 stations along 4 different Ría-to-shelf transects over a 4 d period from the Rías Baixas. The Rías of Muros, Arosa, Pontevedra and Vigo were sampled on 18, 19, 20 and 21 September respectively (Fig. 1), using 0.7 and 5.01 Niskin bottles with reversing Watanabe thermometers, at sample depths of $0,5,10,20,30,40,50,60,80,100$, 120 and $150 \mathrm{~m}$, shelf depth permitting. Temperature was recorded from the Watanabe thermometers and corrected using the non-simplified equation of Ander-

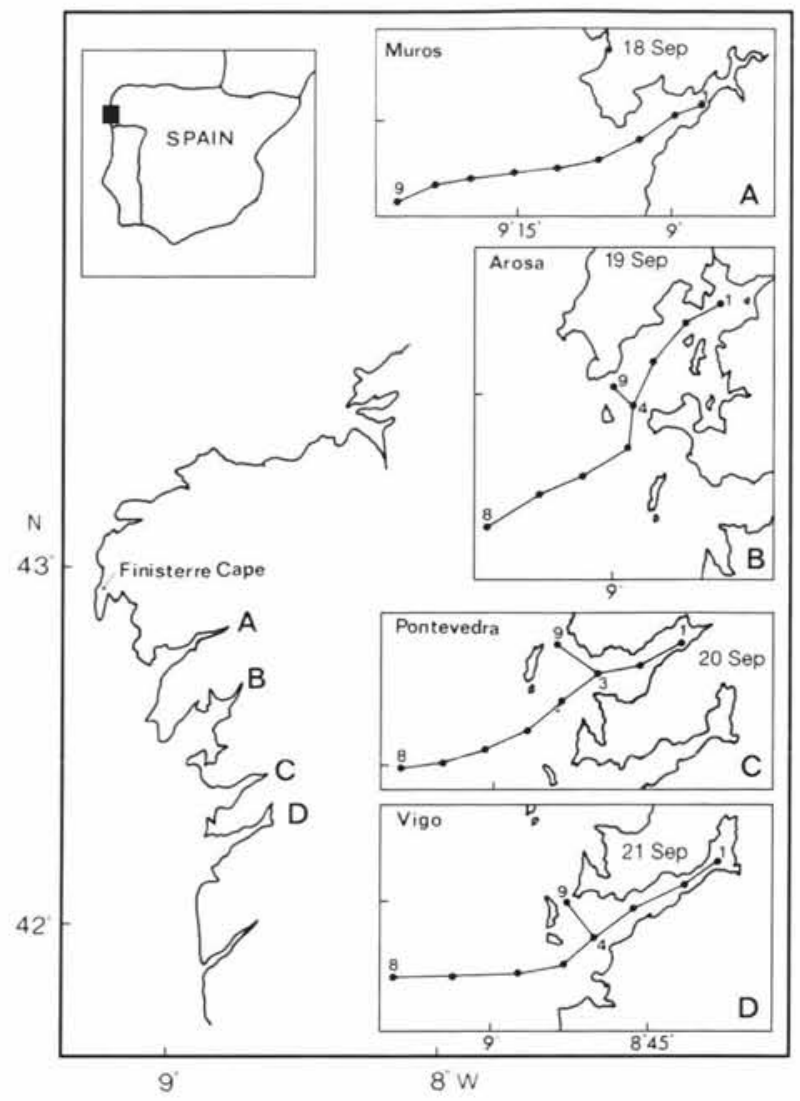

Fig. 1. The Rías of Muros, Arosa, Pontevedra and Vigo, Galicia, NW Spain, showing transects and sampling stations

son (1974). Aliquots were taken from the Niskin bottles to determine the following hydrographic parameters; directly after sampling, nutrients were measured on board with autoanalysers. The reduction method to nitrites in a Cd-Cu column (Mouriño \& Fraga 1985) was used to determine nitrates, and the method of Hansen \& Grasshoff (1983) for nitrite, phosphate and silicate determination. Ammonium was measured using the Grasshoff \& Johanssen (1972) method. Chlorophyll $a$ (chl a) was measured fluorometrically. Salinity was derived from Eq. (6) in UNESCO (1981) and conductivity measurements from an Autosal 8400A Salinometer calibrated with 'Standard Water', and temperature-salinity graphs were derived from the results. Density in $\mathrm{kg} \mathrm{m}^{-3}$ minus 1000 (Gamma $\theta$ ) was calculated using Eq. (9) in UNESCO (1986). Geostrophic wind speeds were calculated at Cabo Finisterre 3 times a day at 6 hintervals from 17 to 21 September using pressure charts prepared by Instituto de Meteorología, Madrid (Bol. Met. Diario. 17-21 September 1986) and the method described by Bakun (1973). Cabo Finisterre represents an upwelling index reference point, where the index is assumed to be the same as all of the west coast of Galicia, including the 
Rías Baixas (Blanton et al. 1984). Sea surface wind was estimated by rotating the geostrophic wind vector $15^{\circ}$ to the left and reducing it by $30 \%$ to correct for frictional forces. The square law formula was employed to calculate sea surface stress using the following equation (Bakun 1973):

$$
r=\rho_{\mathrm{d}} C_{\mathrm{d}}|V| V_{\mathrm{n}}
$$

where $\mathrm{r}$ is the stress vector, $\rho_{\mathrm{a}}$ is the density of air, $C_{\mathrm{d}}$ is an empirical drag coefficient, and $V_{\mathrm{n}}$ is the estimated wind vector near the sea surface with magnitude $|V|$. An upwelling index was obtained for each $6 \mathrm{~h}$ interval by dividing $\Upsilon$ by the Coriolis parameter $f\left(9.9 \times 10^{-5}\right)$ which yields an estimate of the surface water flow per kilometer of coast. Average daily indices were calculated from the three 6 hourly values.

Phytoplankton samples were preserved in Lugol's iodine and sedimented in $50 \mathrm{ml}$ composite sedimentation chambers. Diatoms, dinoflagellates flagellates and ciliates (oligotrichous and peritrichous) were identified and counted to species level wherever possible. Naked species which gave poor preservation in Lugol's solution were classified to the nearest genus or group when possible. Utermöhl's (1958) technique was employed to count the phytoplankton species identified, using single transects at $\times 400$ and $\times 250$ for small species and a scan of the whole slide at $\times 100$ for larger forms. Firstly, organisms from all depths in the Ría de Vigo were counted. As would be expected, those depths with no detected chl a yielded very low num- bers of phytoplankton. Thereafter, in subsequent Rías, samples were only counted when chl a was detected. BMDP programme Cluster Analysis (Dixon 1990), and a Principal Component Analysis (PCA) based on correlation matrix were employed to evaluate the structure of the phytoplankton communities. In order to eliminate double zeros, the results present in more than 10 , 20,30 and $40 \%$ of the samples were processed. The PCA made with the species present in more than $20 \%$ of the samples showed the greatest separation in communities, whilst still retaining a statistically significant number of species.

\section{RESULTS}

\section{Hydrographic data}

The Ría transects sampled are shown in Fig. 1. Water density graphs, salinity charts (Figs. 2 to 5 ) and corresponding upwelling indices (Table 1) indicate the varying degrees of upwelling and downwelling found in the 4 Rías. Downwelling occurred on 21 (Index = -38 ) and 20 September $(-26)$, whereas the most intense upwelling was recorded on 18 September (306). The density, salinity and nitrate charts for the Ría de Muros (Fig. 5) did not illustrate an upwelling event corresponding to the upwelling index calculated, but suggested a lag between wind action and water displacement. The low upwelling index calculated for Arosa (13) occurred during a prevalent easterly wind,
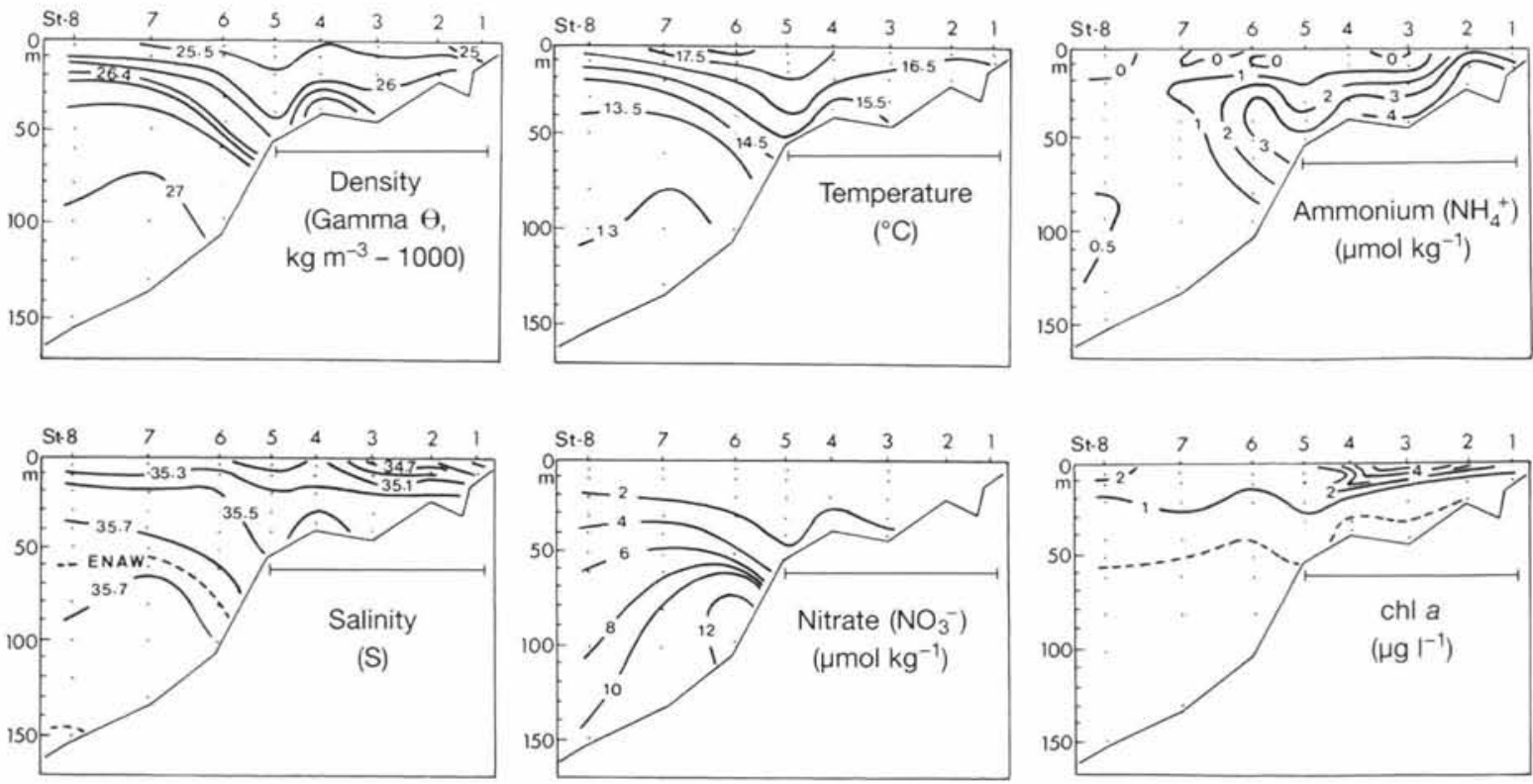

Fig. 2. Distributions of density, salinity, temperature, nitrate, ammonium and chl $a$, Ría de Vigo, 21 September. ENAW: highest limit of Eastern North Atlantic Water. $(\longmapsto)$ Stations in the Ría proper 

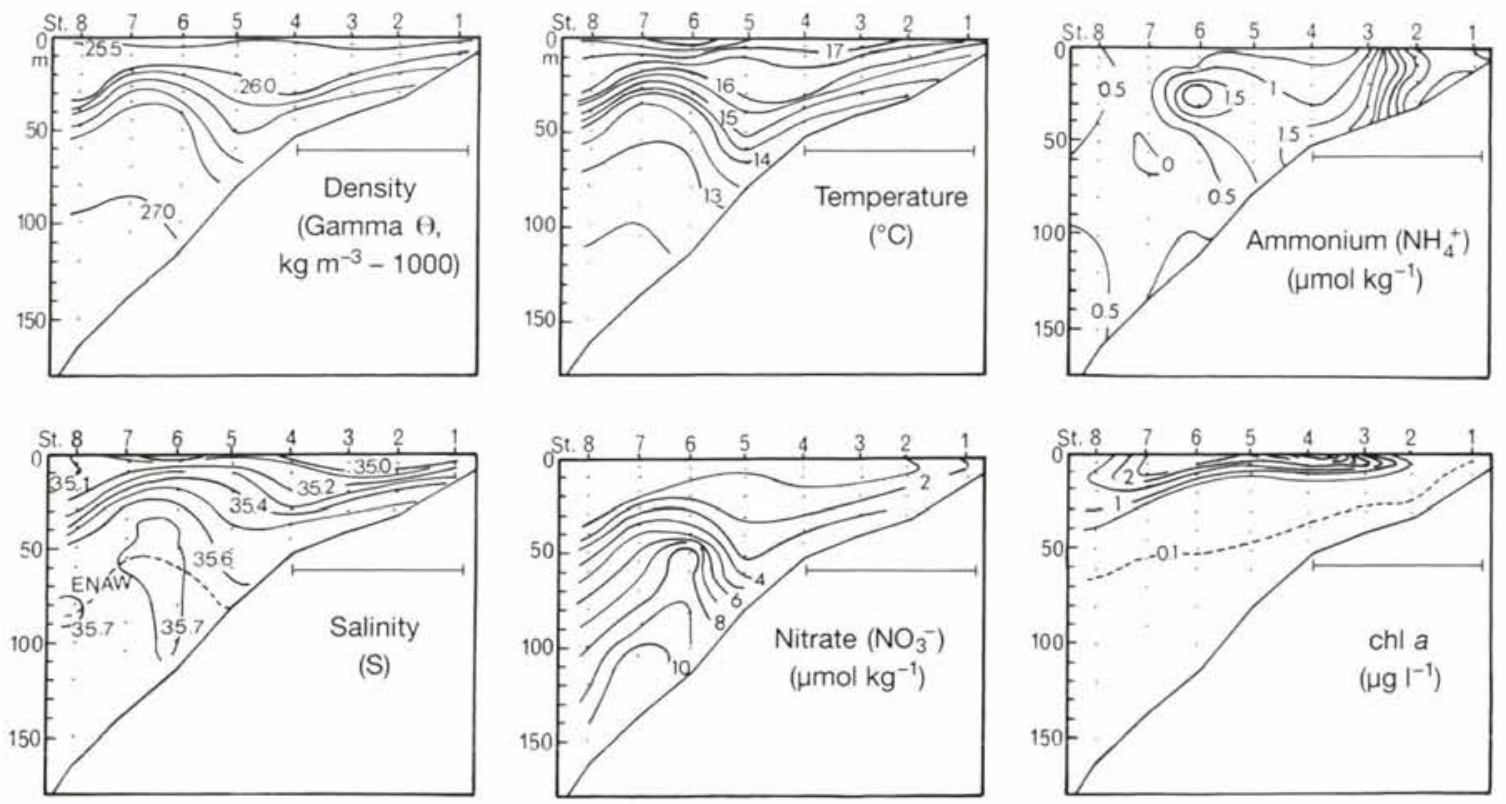

Fig. 3. Distributions of density, salinity, temperature, nitrate, ammonium and chl $a$ in the Ría de Pontevedra on 20 September. $(\longmapsto)$ Stations in the Ría proper

and represents a transitional stage from upwelling to downwelling, which is reflected in the water circulation pattern shown in Fig. 8.

Temperatures (Figs. 2 to 5 ) were greater in surface layers at offshore stations in all of the Rías Baixas, indicating the position of a warmer coastal water. Temperatures were higher in Vigo (max. $18.72^{\circ} \mathrm{C}$ ) and Pon- tevedra (max. $18.79^{\circ} \mathrm{C}$ ) than in the other Rías (Arosa $16.73^{\circ} \mathrm{C}$, Muros $17.64^{\circ} \mathrm{C}$ ), owing to a higher stratification of surface layers.

Salinity values (Figs. 2 to 6 ) in all Rías show a similar trend, with low values in surface layers at Stns $1 \& 2$, corresponding to bodies of less saline water due to river runoff. Low values occur in the offshore surface
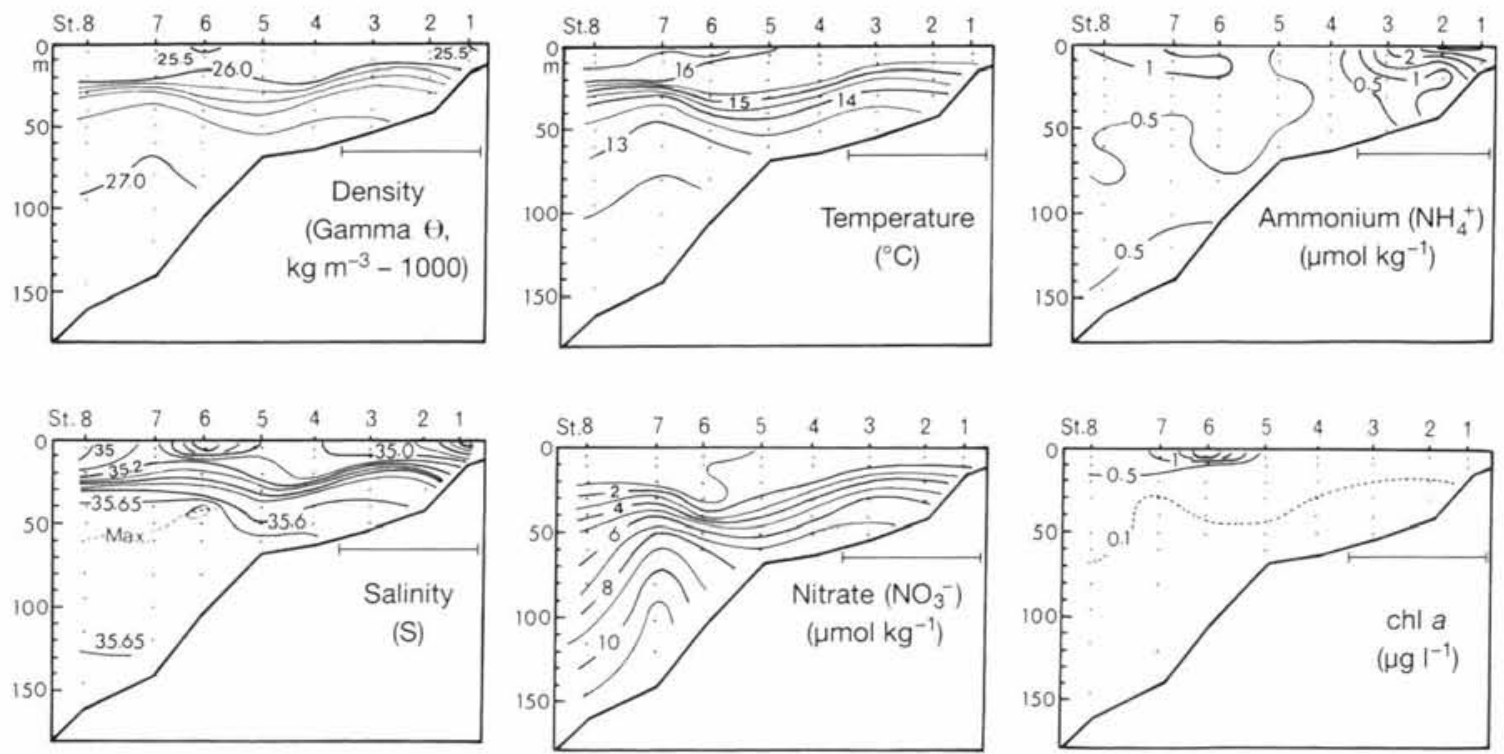

Fig. 4. Distributions of density, salinity, temperature, nitrate, ammonium and chl $a$ in the Ría de Arosa on 19 September. $(\longmapsto)$ Stations in the Ría proper 

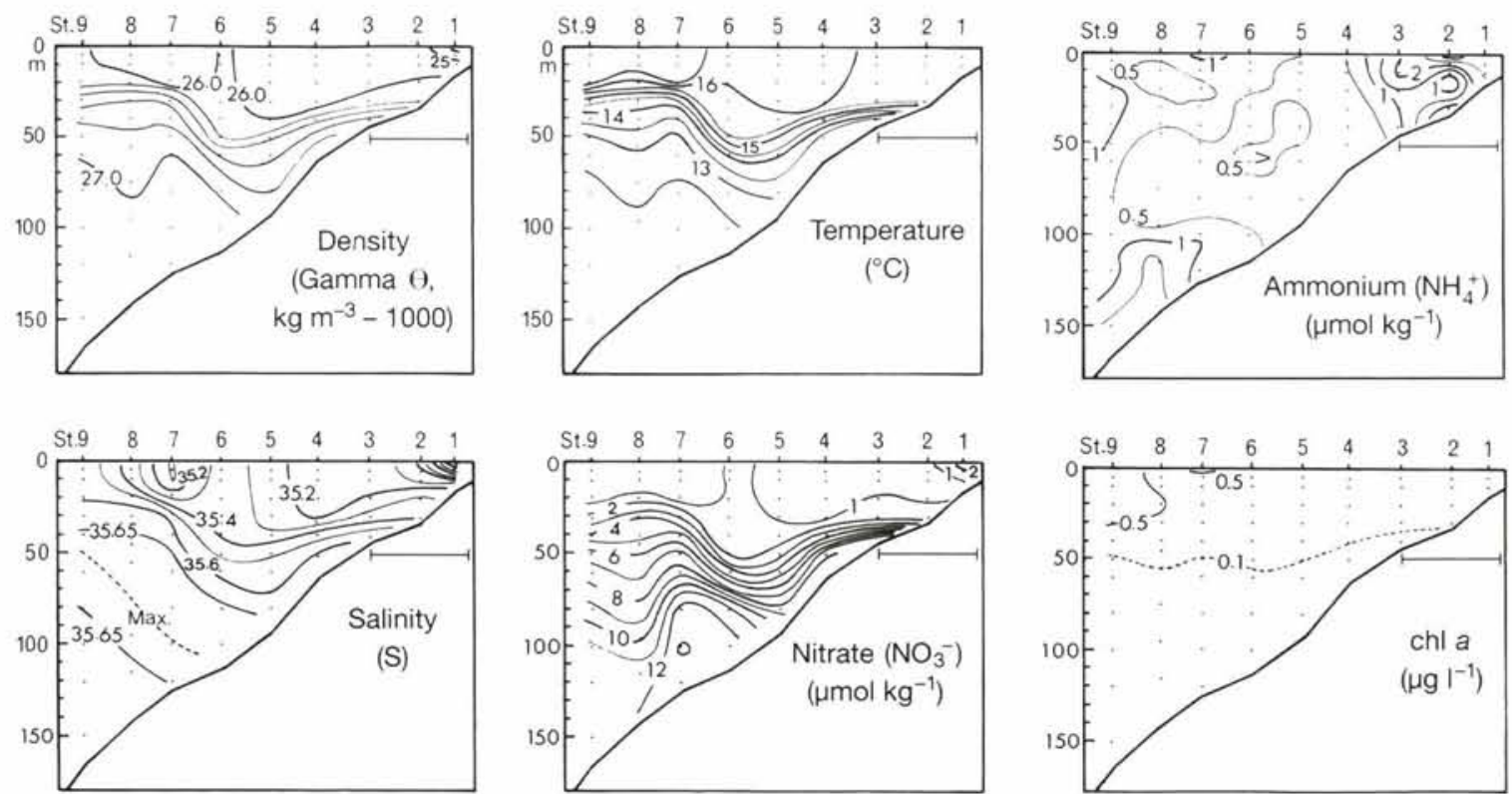

Fig. 5. Distributions of density, salinity, temperature, nitrate, ammonium and chl a in the Ría de Muros on 18 September. $(\longmapsto)$ Stations in the Ría proper

layers at Pontevedra (35.13) and Arosa (34.99). Maximum salinity values occur at deeper shelf layers corresponding to the upper level of ENAW. In the 4 Rías, ENAW was principally Tropical Eastern North Atlantic Water, ENAWt (Ríos et al. 1992).

Nitrate graphs (Figs. 2 to 5 ) show low concentrations $\left(1 \mu \mathrm{mol} \mathrm{kg}{ }^{-1}\right)$ in surface layers of all Rías and down to 20 or $30 \mathrm{~m}$. Domings in nitrate isolines occur over the shelf in all transects, and represent the enrichment of nitrate by ENAW, due to the remineralisation of organic matter (Fraga 1981). Although nitrite levels

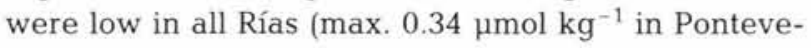
dra), the hydrographic data showed that ammonium, silicate and phosphate levels were present in concentrations, which, in all probability, did not limit phytoplankton growth (data not shown). Ammonium values were higher in the interior of the Rías $\left(4.31 \mu \mathrm{mol} \mathrm{kg}{ }^{-1}\right.$ in Vigo), increased in deeper layers and were lower

Table 1. Average daily upwelling indices $\left(I_{w}\right)$ calculated at Cabo Finisterre

\begin{tabular}{|cc|}
\hline $\begin{array}{c}\text { Date } \\
\text { (September 1986) }\end{array}$ & $\begin{array}{c}I_{\mathrm{w}} \\
\left(\mathrm{m}^{3} \mathrm{~s}^{-1} \mathrm{~km}^{-1} \text { coast) }\right.\end{array}$ \\
\hline 17 & 72 \\
18 & 306 \\
19 & 13 \\
20 & -26 \\
21 & -38 \\
\hline
\end{tabular}

towards the shelf in surface layers. High silicate levels were detected in deeper layers, especially in the interior of all Rías, where the effect of river runoff and silicate leaching from granite river basins is greater

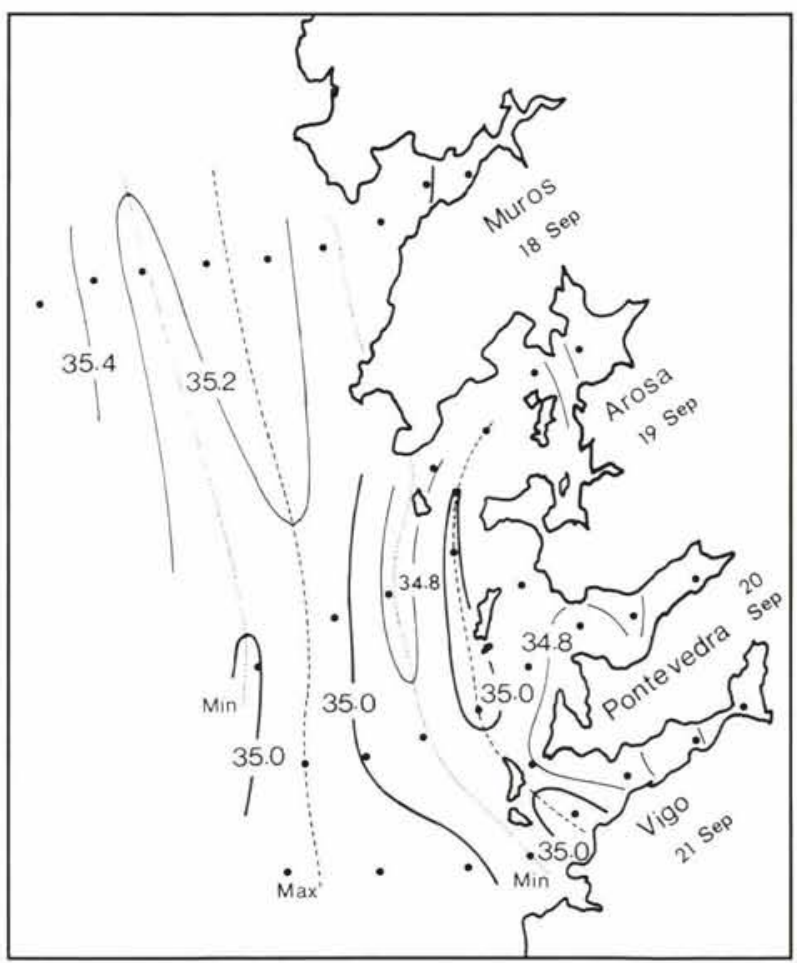

Fig. 6. Distribution of surface salinity 

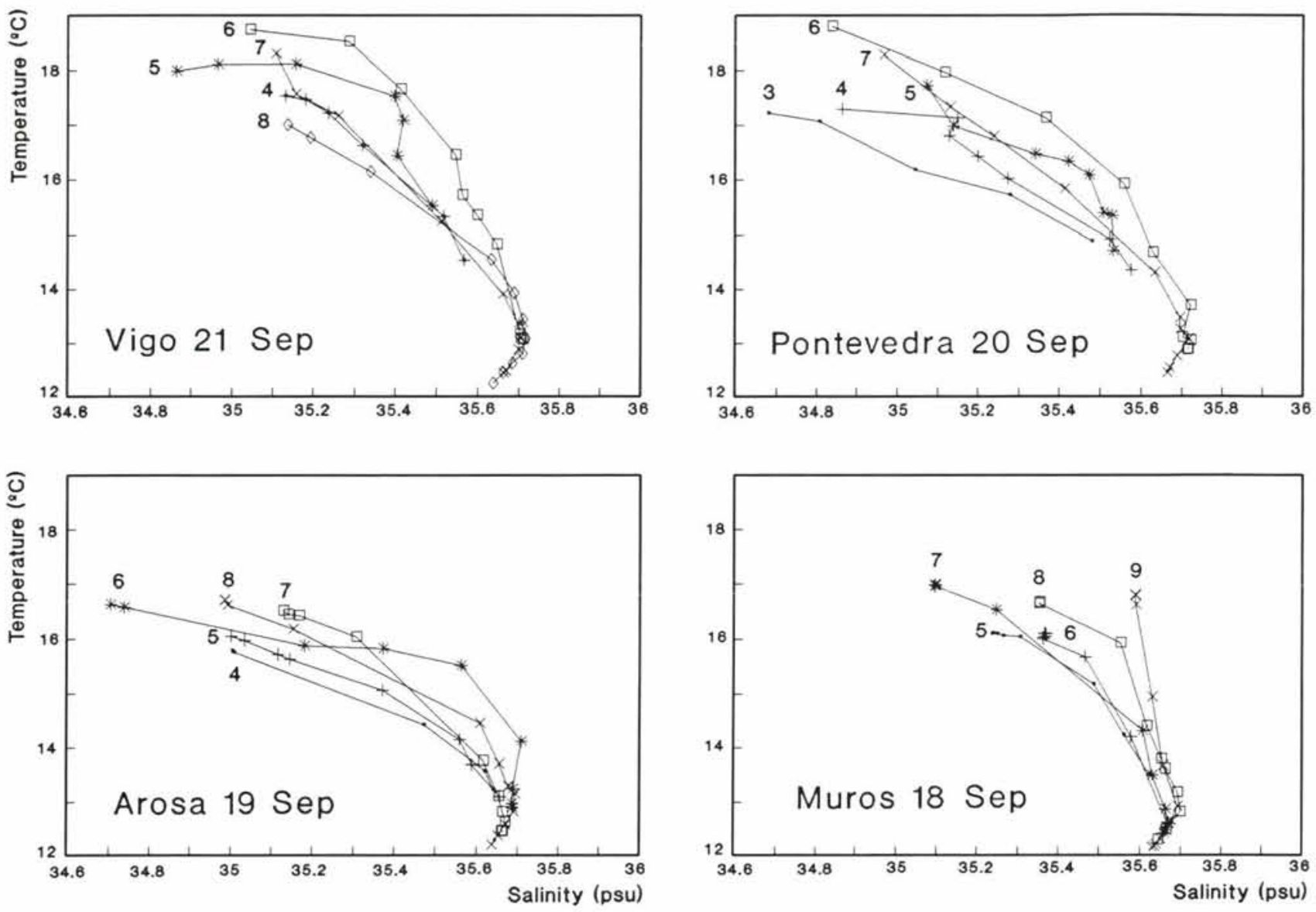

Fig. 7. Temperature-salinity diagrams, Rías of Vigo, Pontevedra, Arosa and Muros

(Pérez et al. 1992). At all interior stations, values higher than $7.0 \mu \mathrm{mol} \mathrm{kg}{ }^{-1}$ were present, with a maximum of $12.0 \mu \mathrm{mol} \mathrm{kg}^{-1}$ for Muros and a minimum of $7.04 \mu \mathrm{mol}$ $\mathrm{kg}^{-1}$ for Arosa. Phosphate levels in the surface water of the Rías Baixas were low, but as might have been expected, maximum values occurred in the inner zone of the Rías due to the input from rivers. The highest values were recorded in Pontevedra $\left(0.79 \mu \mathrm{mol} \mathrm{kg}^{-1}\right)$ and the lowest in Muros $\left(0.49 \mu \mathrm{mol} \mathrm{kg}^{-1}\right)$.

From the temperature-salinity (T-S) sections shown in Fig. 7 and the hydrographic data in Figs. 2 to 5, general patterns of water circulation for Vigo, Pontevedra, Arosa and Muros (Fig. 8) were derived. The boundary layer between ENAW and Ría water showed high nitrate concentrations on the shelf floor. These concentrations (shaded area in Fig. 8) were higher than those corresponding to the ENAW (Fraga 1981), indicating that the boundary layer is a zone of low mixing and slow circulation allowing accumulation of regenerated nutrients. The T-S plots for Vigo (Fig. 7) show that Stns $4,7 \& 8$ had the same thermohaline properties. Stn 6, however, showed a warmer water body situated between 0 and $40 \mathrm{~m}$, probably a branch of surface coastal water. Temperature and salinity values above $40 \mathrm{~m}$ for Stn 5 lie between those measured at Stns 6 \& 7. Nevertheless, below this depth, T-S characteristics were similar to those for Stns $4 \& 7$ (Fig. 7). The observed hydrographic structure could only be generated if the nucleus of water at $\operatorname{Stn} 4$, isolated and unstable, had penetrated during a previous upwelling, as illustrated by the coinciding positions of the T-S lines for Stns $4 \& 7$ (Fig. 7). This water body became confined to the interior of the Ría, turning cyclonically and blocking the outflow of Ría water. The interchange of surface Ría water was disrupted, and consequently became confined in a semi-closed circuit (Fig. 8).

Salinity graphs and T-S sections for Pontevedra (Figs. $3 \& 7$ ) illustrate the presence of ENAW from the shelf at Stns $6,7 \& 8$, rising to $70 \mathrm{~m}$ at Stns $6 \& 7$. The crossing of the T-S lines derived for Stns 4 \& 5 (Fig. 7) points to this region as a mixing zone due to downflowing of Warm Coastal Water, that blocked the outflow of water from the interior of the Ría. The ultimate result of this process is the formation of a less advanced semiclosed circulation as described for Vigo by Fraga \& Prego (1989). 

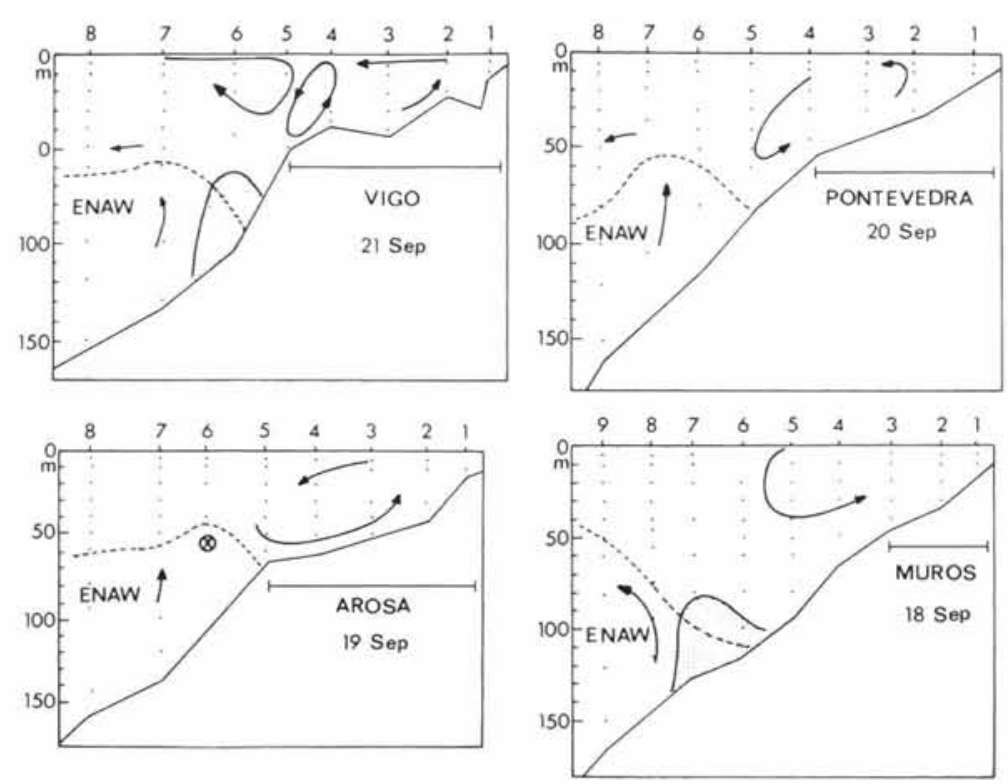

Fig. 8. Residual water circulation patterns, Rías of Vigo, Pontevedra, Arosa and Muros. Shaded area represents zone of slow transport with remineralisation of organic matter. $(\longmapsto)$ Stations in the Ría proper

In Arosa, salinity and temperature graphs (Fig. 4) show the position of warmer and less saline water at offshore surface layers. The crossing of T-S lines (Fig. 7) at Stns $6 \& 7$ around $20 \mathrm{~m}$ indicates lateral mixing. The input of ENAW from deep shelf layers has a slight influence on the flow of coastal water, pushing it upwards.

In the Ría de Muros, open exchange exists between the passage of Ría water to the shelf (Fig. 8). Weak downwelling was observed only at Stns $5 \& 6$ below $50 \mathrm{~m}$ depth (Fig. 5). The input of ENAW, from the bottom of the shelf, mixes with the Ría water, pushing it upward towards Stns $8 \& 9$. As in the other Rías, there is a band of less saline water at the shelf surface layer down to $10 \mathrm{~m}$, which extends from the south to this Ría, and probably moves northwards with the change in wind direction.

Taking into account the time ( 4 d) elapsed between sampling in Muros and Vigo, and since the motion of coastal water is derived from large-scale phenomena, it is possible that the water circulation patterns described for Muros could have been previously encountered in Vigo. Arosa and Pontevedra would then represent intermediate stages in downwelling formation.

\section{Chlorophyll a}

High chl a concentrations were found in surface layers down to $10 \mathrm{~m}$ in the interior of the Ría de Vigo (5.9 $\mathrm{g} \mathrm{I}^{-1}$; Fig. 2), and at shelf stations and in the inte- rior of the Ría de Pontevedra $\left(5.14 \mu \mathrm{g} \mathrm{l}^{-1}\right.$; Fig. 3). It was, however, significantly less over the shelves of Arosa $\left(2.45 \mu \mathrm{g} \mathrm{l}^{-1}\right.$; Fig. 4) and Muros (0.80 $\mathrm{\mu g} \mathrm{l}^{-1}, 20 \mathrm{~m}$; Fig. 5), which were displaced from the Ría to the shelf with the outflow of surface Ría water. A maximum concentration of the chlorophyll in the Ría de Vigo (Fig. 2), between Stns 1 \& 5, coincided with the confinement of Ría water and low nitrate $(0.30 \mu \mathrm{mol}$ $\left.\mathrm{kg}^{-1}\right)$, nitrite $\left(0.19 \mu \mathrm{mol} \mathrm{kg}{ }^{-1}\right)$, ammonium $\left(0.28 \mu \mathrm{mol} \mathrm{kg}^{-1}\right)$ and phosphate $(0.33 \mu \mathrm{mol}$ $\left.\mathrm{kg}^{-1}\right)$, but higher silicate $\left(5.47 \mu \mathrm{mol} \mathrm{kg}{ }^{-1}\right)$. In the Ría de Pontevedra (Fig. 3), a lower chl a concentration at Stn 5 corresponds to a zone of mixing of coastal and Ría water, as described above. On the previous day in the Ría de Arosa (Fig. 4), the chlorophyll maximum occurred over the shelf between Stns $5 \& 7$ coinciding with a decrease in the level of nitrate $\left(0.08 \mu \mathrm{mol} \mathrm{kg} \mathrm{kg}^{-1}\right)$, nitrite $\left(0.08 \mu \mathrm{mol} \mathrm{kg} \mathrm{kg}^{-1}\right)$, phosphate $(0.07 \mu \mathrm{mol}$ $\left.\mathrm{kg}^{-1}\right)$ and silicate $\left(2.06 \mu \mathrm{mol} \mathrm{kg} \mathrm{kg}^{-1}\right)$ and higher levels of ammonium $(0.36 \mu \mathrm{mol}$ $\mathrm{kg}^{-1}$ ). The position of this maximum correlates with the position of less saline water as in Muros (Fig. 5), where higher levels of nitrate $\left(0.68 \mu \mathrm{mol} \mathrm{kg}{ }^{-1}\right)$ and ammonium $\left(1.26 \mu \mathrm{mol} \mathrm{kg}{ }^{-1}\right)$ are evident. Thus, in regions of high chlorophyll, nitrate and ammonium levels were low. In Muros, where the chlorophyll concentration was far lower, nitrate and ammonium levels were higher.

\section{Phytoplankton distribution}

A total of 302 species were identified from the 172 samples taken from the Rías Baixas: 84 species of diatoms, 144 dinoflagellates, 16 flagellates, 40 oligotrichous ciliates and 13 periotrichous ciliates. Although the greatest variation in species was in the dinoflagellates, the flagellates were the most abundant with more than 100000 cells $1^{-1}$ in some surface stations. The chl a maximum in the interior of the Ría de Vigo was dominated by the flagellate Heterosigma carterae, unidentified small flagelates, Thalassiosira nana, Rhodomonas sp. and Gymnodinium nanum. G. catenatum ranked 7 th in the order of abundance at the chl a maximum. In the interior of the Ría de Pontevedra at Stn 4, H. carterae and unidentified small flagellates were the most abundant, with G. simplex and small Chaetoceros spp, showing secondary dominance. At shelf Stns 6 \& 7, diatoms were most abundant and were dominated by Chaetoceros socialis, C. radians and small and medium centric diatoms. Unidentified small flagellates Cryptophyceae spp. and 
Table 2. Loads (correlation coefficients) of the 40 species and taxa selected for PCA of the first 3 principal components. Species are ordered according to PC1. The higher loads for PC2 and PC3 are in bold type. Taxon codes refer to dendrogram in Fig. 10

\begin{tabular}{|c|c|c|c|c|}
\hline Code & Taxon & PC1 & $\mathrm{PC} 2$ & PC3 \\
\hline 35 & Oligotrichous ciliates (small, $<30 \mu \mathrm{m}$ ) & 0.87 & 0.05 & 0.058 \\
\hline 16 & Torodinium robustum Kofoid \& Swezy & 0.813 & 0.018 & 0.053 \\
\hline 17 & Gymnodinium nanum Schiller & 0.809 & -0.117 & 0.145 \\
\hline 11 & Cochlodinium helix (Pouchet) Lemmemann & 0.792 & 0.073 & 0.044 \\
\hline 36 & Oligotrichous ciliates (medium, $30-60 \mu \mathrm{m}$ ) & 0.789 & 0.045 & -0.092 \\
\hline 03 & Centric diatom spp. (medium, $30-60 \mu \mathrm{m}$ ) & 0.687 & 0.092 & -0.235 \\
\hline 39 & Peritrichous ciliates (medium, 30-60 $\mu \mathrm{m}$ ) & 0.636 & -0.062 & \\
\hline 30 & Heterosigma carterae (Hulburt) Taylor & 0.629 & 0.414 & 35 \\
\hline 10 & Dinoflagellate spp. (medium, $30-60 \mu \mathrm{m}$ ) & 0.604 & 0.012 & -0.0 \\
\hline 22 & Gyrodinium fusiforme Kofoid \& Swezy & 0.602 & 0.096 & 0.228 \\
\hline 31 & Cryptophyceae spp. & 0.534 & 0.160 & 0.103 \\
\hline 15 & Gymnodinium catenatum Graham & 0.476 & 0.543 & -0.205 \\
\hline 18 & Gymnodinium spp. (small, $<30 \mu \mathrm{m}$ ) & 0.465 & 0.149 & -0.019 \\
\hline 02 & Stauroneis membranacea Cleve & 0.443 & 0.346 & -0.379 \\
\hline 33 & Strombidium strobilum (Lohmann) Wulf & 0.411 & 0.553 & -0.021 \\
\hline 13 & Scrippsiella trochoidea (Stein) Loeblich & 0.386 & 0.359 & 0.241 \\
\hline 04 & Chaetoceros sp. (small, $<30 \mu \mathrm{m}$ ) & 0.37 & 0.262 & -0.338 \\
\hline 28 & Amphidinium flagellans Schiller & 0.344 & 0.419 & 0.390 \\
\hline \multirow[t]{2}{*}{34} & Mesodinium pulex (Claparede \& Lachmann) & & & \\
\hline & & 0.266 & 0.229 & 0.268 \\
\hline 09 & Dinoflagellate cysts (small, $<30 \mu \mathrm{m}$ ) & 0.213 & 0.064 & -0.035 \\
\hline 20 & Cachonina niei Loeblich & 0.206 & 0.402 & 0.037 \\
\hline 05 & Centric diatom spp. (small, $<30 \mu \mathrm{m}$ ) & 0.112 & 0.131 & -0.09 \\
\hline 06 & Nitzschia seriata Cleve & 0.075 & 0.356 & -0.117 \\
\hline 38 & $\begin{array}{l}\text { Mesodinium rubrum (Lohmann) Hamburger } \\
\text { \& Buddenbrok }\end{array}$ & 0.037 & 0.563 & 0.461 \\
\hline 40 & Peritrichous ciliates (small, $<30 \mu \mathrm{m}$ ) & 0.02 & 0.074 & 0.493 \\
\hline 23 & $\begin{array}{l}\text { Ceratium furca (Ehrenberg) Claparede \& } \\
\text { Lachmann }\end{array}$ & 0.003 & 0.327 & -0.306 \\
\hline 21 & $\begin{array}{l}\text { Protoperidinium divergens (Ehrenberg) } \\
\text { Balech }\end{array}$ & 0.028 & 0.636 & -0.298 \\
\hline 08 & Gymnodinium varians Maskell & -0.08 & 0.181 & 0.283 \\
\hline 26 & Ceratium fusus (Ehrenberg) Dujardin & -0.125 & 0.628 & -0.028 \\
\hline 12 & Protoperidinium depressum (Bailey) Balech & -0.133 & 0.458 & -0.116 \\
\hline 14 & Dinoflagellate spp. (small, $<30 \mu \mathrm{m}$ ) & -0.206 & 0.113 & 0.251 \\
\hline 01 & Coscinodiscus spp. & -0.242 & 0.148 & -0.433 \\
\hline 29 & Ceratium horridum Gran & -0.336 & 0.673 & -0.031 \\
\hline 27 & Noctiluca scintillans (Macartney) Ehrenberg & -0.399 & 0.482 & -0.109 \\
\hline 37 & Strombidium turbo Claparede \& Lachmann & -0.406 & 0.365 & 0.408 \\
\hline 07 & Proboscia alata (Brightwell) Sundström & -0.408 & 0.419 & 0.397 \\
\hline 25 & Gymnodinium agiliforme Schiller & -0.428 & 0.300 & 0.190 \\
\hline 19 & Ceratium tripos (Müller) Nitzsch & -0.454 & 0.585 & -0.175 \\
\hline \multirow[t]{2}{*}{24} & zacroceros (Ehrenberg) & & & \\
\hline & & -0.480 & 0.420 & -0.407 \\
\hline 32 & Unidentified small flagellates $(<30 \mu \mathrm{m})$ & -0.534 & 0.442 & 0.191 \\
\hline
\end{tabular}

From the PCA analysis, PCA $20 \%$ (Table 2 ) yielded the highest variation between loads and thus the best separation between the communities. PCA $20 \%$ explained $40 \%$ of the total variation in 40 species selected from the samples. The first component, PC1, explained $22 \%$, PC2 explained $13 \%$ and PC3 explained $6 \%$ of the variation.

Of the 40 species included in this analysis, 26 had positive and 14 had negative correlations with PC1 (Table 2). High positive correlations were recorded for small and medium oligotrichous ciliate and dinoflagellate species. The distribution of the scores of this component (Fig. 9) correlate with the position of the $\mathrm{chl} a$ maximum in the interior of the Rías of Vigo and Pontevedra (Figs. 2 \& 3). An association of unidentified small flagellates, Ceratium macroceros, $C$. tripos, Gymnodinium agiliforme and Proboscia alata, showed negative values, which coincided with the position of the chl a maximum at Pontevedra (Stn 6), Arosa (Stn 7) and Muros (Stns $7 \&$ 8). PC1 therefore indicates differences between phytoplankton associations in the interior of the lower Rías Baixas and the exterior of the higher Rías.

Similarly, the cluster analysis (Fig. 10) yielded 2 clusters at the $40 \%$ level. These broad-scale separations are nearly identical to those of the PC1 analysis, indicating that the community segregation was not solely a result of the analysis utilised. Only the grouping of Mesodinium rubrum, Ceratium furca and medium-sized Periotrichous spp. ciliates differed.

The PC2 analysis resulted in 38 species with positive correlations (Table 2), defining a community of Ceratium horridum, Protoperidinium divergens,

Solenicola setigera also occur in high numbers in this zone. Like interior stations for Vigo and Pontevedra, the chl a maximum at Stns 6 \& 7 of Arosa were due predominantly to $H$. carterae and unidentified small flagellates, plus Ceratium horridum and Proboscia alata. In Muros, where the maximum is markedly lower, small flagellates, P. alata, C. horridum and Mesodinium rubrum, dominated the phytoplankton. G. catenatum was absent from this assemblage.
C. fusus and C. tripos principally, plus red tide species such as Mesodinium rubrum, Gymnodinium catenatum and Heterosigma carterae at background levels. High positive correlations are situated at Stns $4 \& 5$ of the Ría de Vigo (Fig. 11), throughout Pontevedra with a maximum at Stn 6 , in Arosa at Stns $6 \& 7$ and at the shelf stations of Muros. This community is an indication of a band of less saline water situated along the coast, produced by a change in wind direction, from 

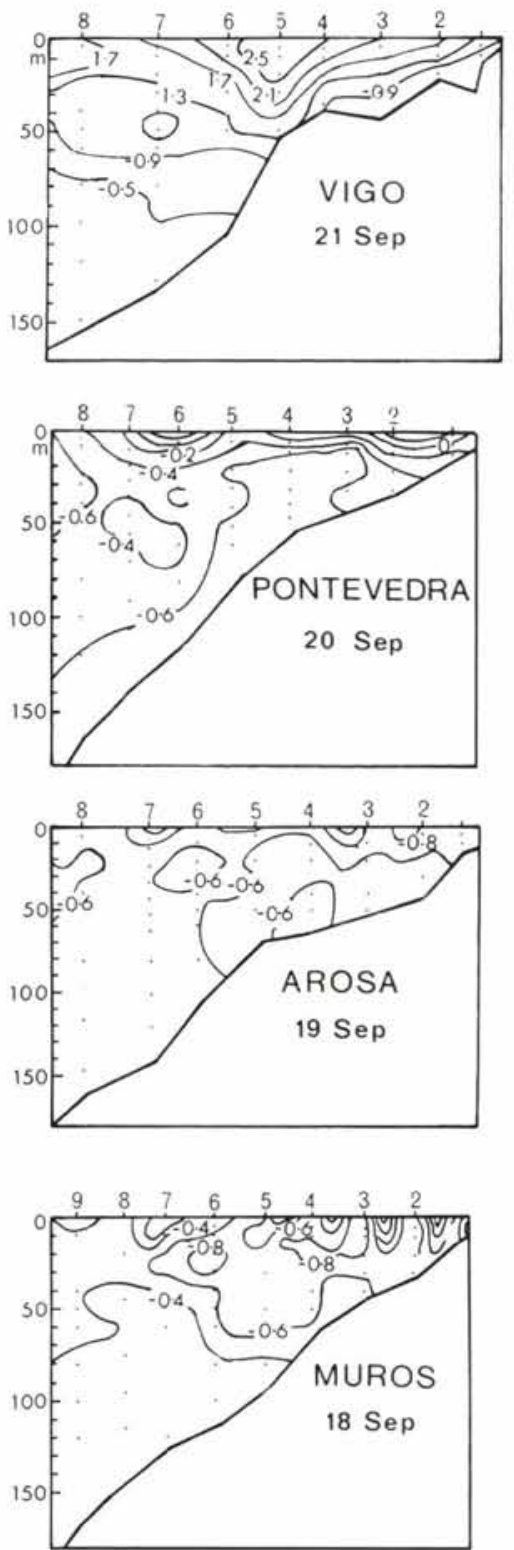

Fig. 9. Distribution of scores of the principal component PC1, Rías of Vigo, Pontevedra, Arosa and Muros

north to south (Fig. 6). The highest positive scores were recorded in Arosa. The abundance of these key species varies between the Rías. For example, data for the total number of species for each Ría (not included) show that Pontevedra has the highest number of $C$. horridum

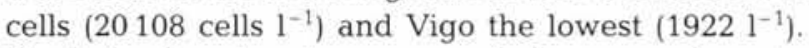
Similarly G. catenatum occurs in large numbers in Vigo $\left(11583 \mathrm{l}^{-1}\right)$ and is absent from Muros. Negative isolines (Fig. 11) represent the absence of this PC2 community, since only 2 species were recorded with negative loads.

Small peritrichous ciliates, Mesodinium rubrum, Strombidium turbo, Proboscia alata, plus small dino-
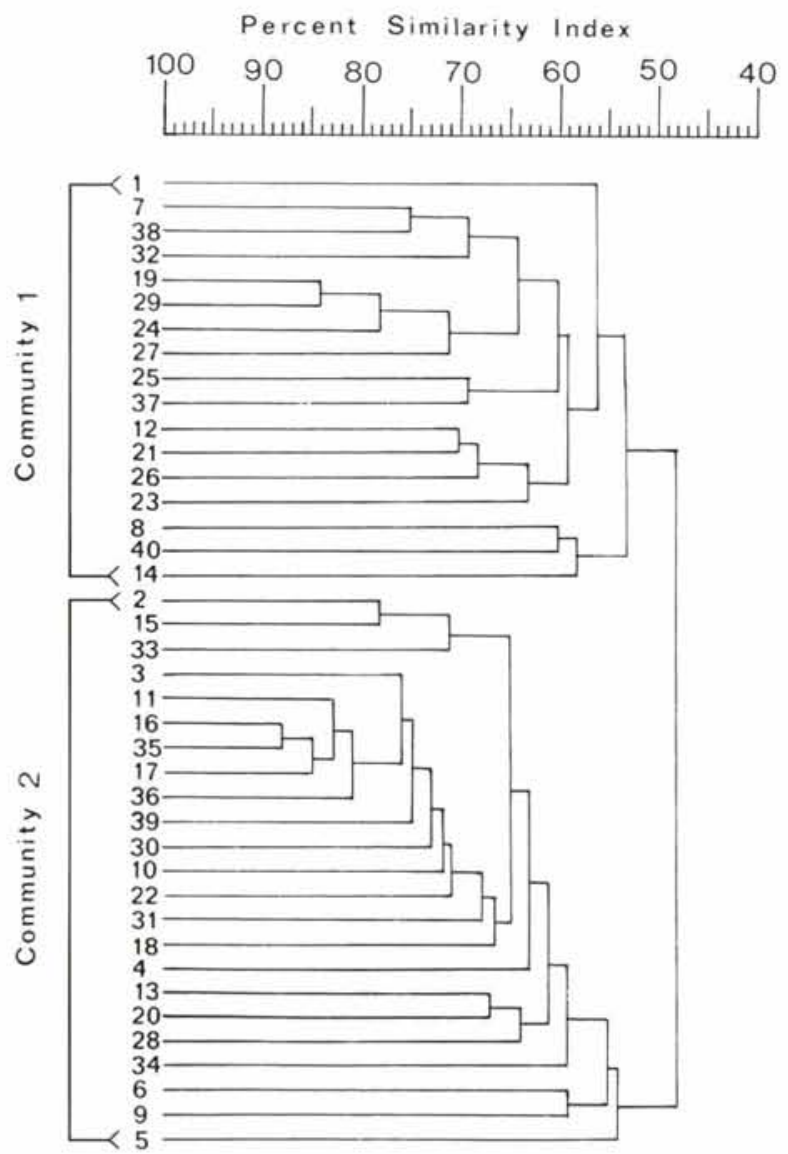

Fig. 10. Dendrogram for the percent similarity of phytoplankton samples collected from all of the Riás and prepared by the group average linkage method. Taxon codes given in Table 2

flagellates exhibited positive correlations for the PC3 analysis (Table 2) in all interior stations of the Rías, with highest scores occurring in Pontevedra and Vigo (Fig. 12). Predominantly negative correlations were recorded for diatoms, including Coscinodiscus spp., Stauroneis membranacea and small Chaetoceros spp., which were situated mainly at the surface, but also in deeper layers at Vigo, Pontevedra and Arosa (Fig. 12).

Fig. 13 shows the surface distribution of the major phytoplankton associations derived from the PCA $20 \%$ analysis. A clear separation occurs between an interior Rías community $(\mathrm{PC} 3+)$ which extends over the shelf in Muros, and coincides with the position of Ría water (Fig. 6). A shelf community of large dinoflagellates and red tide species $(\mathrm{PC} 2+)$ penetrates further into the lower Rías, and corresponds with a band of less saline water that extends north to south along the coast (Fig. 6). An offshore community of diatoms (PC3 -) is situated in front of the Rías of Vigo, Pontevedra and Arosa, and coincides with surface coastal water (Fig. 6). 

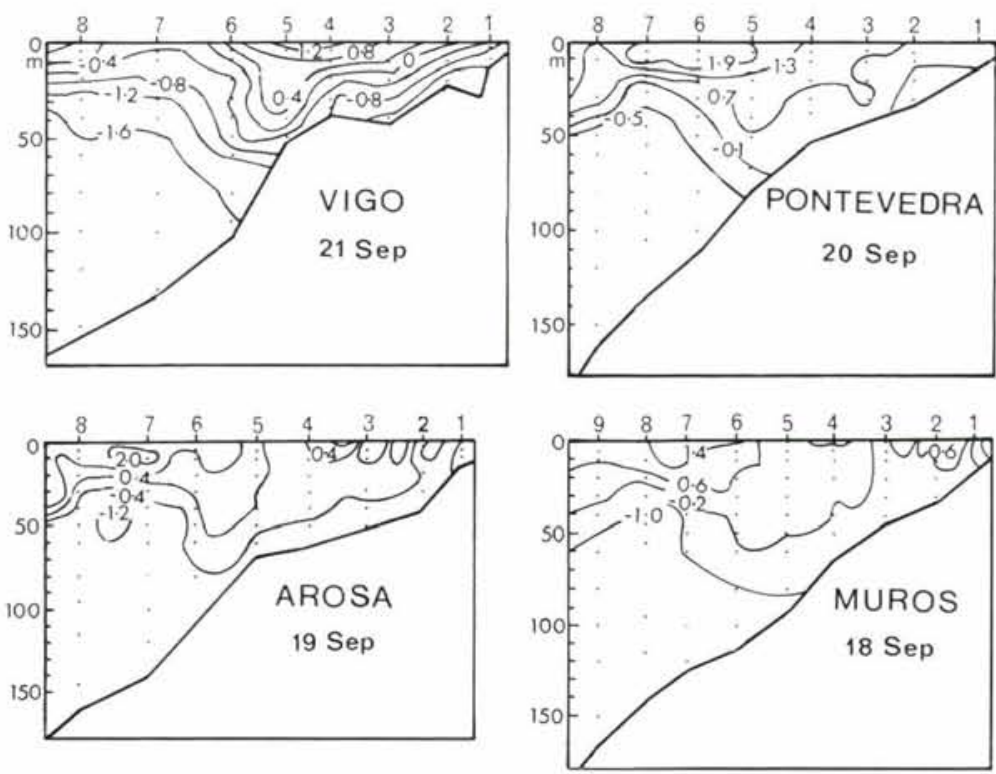

Fig. 11. Distribution of scores of the principal component PC2, Rías of Vigo, Pontevedra, Arosa and Muros
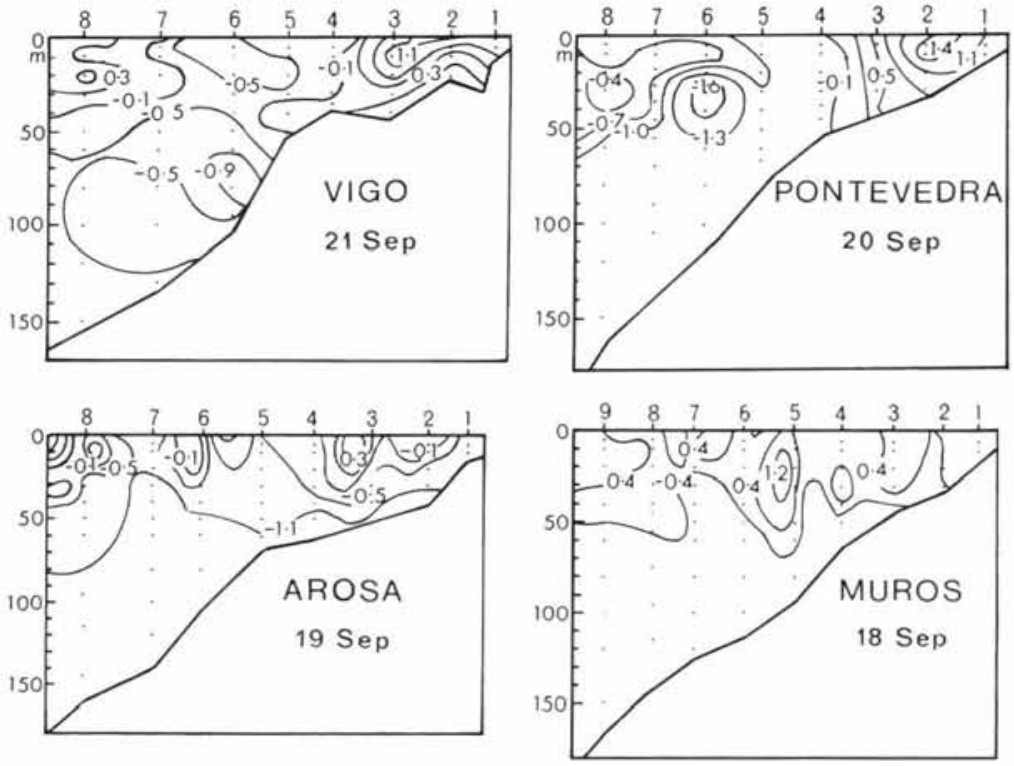

Fig. 12. Distribution of scores of the principal component PC3, Rías of Vigo, Pontevedra, Arosa and Muros

\section{DISCUSSION}

During the upwelling season, surface water moves north to south along the west coast from Cabo Finisterre (Fraga et al. 1982, Blanton et al. 1984, Castro et al. 1994). In front of the Rías, upwelling is favoured by north winds from April to August, and a south wind during the rest of the year favours downwelling (Fraga
1981, Estrada 1984). During upwelling. the chl a maximum becomes restricted to a narrow band off the Rías Baixas (Varela 1992). Late summer normally favours the blooming of the diatoms Rhizosolenia delicatula, R. shrubsolei and Proboscia alata over the shelf (Varela et al. 1987). Nitzschia seriata and Leptocylindrus danicus bloom in the interior of the Rías (Varela 1982, Figueiras \& Niell 1987). The distribution and composition of the phytoplankton varies with the intensity of upwelling and consequent outflow from the Rías. Strong upwelling causes greater outflow and a high phytoplankton biomass is encountered on the west shelf (Varela 1992). Weak upwelling injects nutrients to just below the photic layer and favours the growth of motile dinoflagellates (Figueiras \& Ríos 1993). A change in wind direction from north to south, and a higher wind speed, also recorded during previous Septembers, result in downwelling over the shelf (Blanton et al. 1984, McClain et al. 1986, Fraga \& Prego 1989), whereas weaker wind speeds cause upwelling relaxation (Fiuza 1983, Castro et al. 1994). Although Fraga et al. (1988, 1990) claim that blooms are introduced from oceanic stations into the Rías during downwelling events, Figueiras et al. (1994) show that red tide organisms form during weak upwelling in the outer part of the Ría, and become concentrated in the interior during downwelling.

The data generated from the Galicia IX 1986 cruise indicates that the effect of upwelling and outflow before 18 September (Table 1) was the spreading of a community dominated by small ciliates, Proboscia alata, small dinoflagellates, throughout the surface water of the Ría de Muros and adjacent shelf. At offshore stations, a community of large dinoflagellates and red tide species existed. A change in wind direction and in the associated water circulation caused downwelling and the establishment of a semi-closed circulation pattern in Pontevedra and Vigo on 20 and 21 September respectively. The small ciliate/ $P$. alata/small dinoflagellate community became confined to the interior of the Rias of Vigo, Pontevedra and Arosa, and the large dinoflagellate/red tide species community was forced from the shelf towards the mouth of the Rías. 


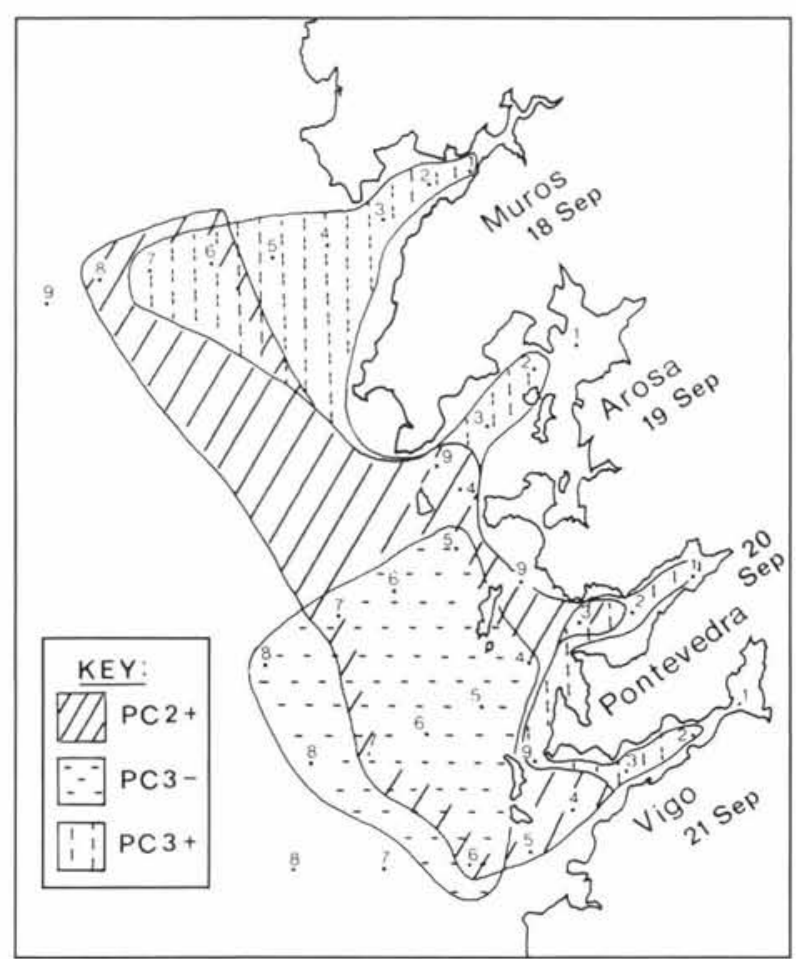

Fig. 13. Surface distribution $(0$ to $10 \mathrm{~m})$ of phytoplankton communities identified by principal component analysis

Low cell numbers and chl a maximum in Muros on 18 September was possibly due to the outflow of Ría water. The effect on phytoplankton was displacement and probably lower division rates owing to more turbulent conditions (Thomas \& Gibson 1990). Similar hydrographic conditions and chl a distributions, found in Muros, possibly occurred in the other Rias Baixas under the same hydrographic conditions. The temporal change observed from Muros to Vigo is probably the general sequence of each Ría, and slight differences in water circulation among the Rías will exist, due to their geographical position and topography (Tenore et al. 1982).

The distribution of the large dinoflagellate and red tide species $(\mathrm{PC} 2+$ ) corresponds to the position of a less saline water body, shown in the salinity chart (Figs. 6 \& 13). The movement of the large dinoflagellate/red tide species community from the shelf into the lower Rías during downwelling on 20 September introduced Gymnodinium catenatum into a favourable environment for growing, with relatively high nutrient concentrations (especially ammonium) and strong stratification. Downwelling convergence at estuarine frontal boundaries and the confinement of a water body may provide regions of concentration and proliferation for red tide organisms (Margalef et al. 1979, Tyler \& Seliger 1981, Anderson et al. 1982). Smaller forms occurred in the interior of the Ría during downwelling, which was also described by Varela et al. (1991) and the shelf hosted larger dinoflagellates.

The growth of Gymnodinium catenatum thus occurred over the shelf and was initiated by a previous upwelling event, which did not break the water stratification (Figueiras \& Pazos 1991a). Upwelling followed by downwelling, which moved the species from the shelf to a favourable growth environment in the interior of the Rías, may prove to be an important mechanism in red tide formation in all coastal upwelling systems. Differences in the intensity of the bloom will exist, owing to the geomorphological structure of the coastline, where bays act as catchment zones for concentrating the red tide.

Acknowledgements. We acknowledge the captain, crew and technical staff of the RV 'García del Cid' during the Galicia IX cruise. We also thank C. Castro and Dr X. A. Alvarez-Salgado for their help with the T-S sections, water circulation patterns and upwelling indices. This work was funded by grant PR840068 of the Comisión Asesora de Investigación Científica y Técnica and a scholarship to G.H.T. from the CSIC-BC.

\section{LITERATURE CITED}

Anderson, D. M., Kulis, D. M., Orphanus, J. A., Ceurvels, A. R. (1982). Distribution of toxic dinoflagellate Gonyaulax tamarensis in the south New England region. Estuar. coast. Shelf. Sci. 14: 447-458

Anderson, L. (1974). Correction of reversing thermometers and related depth calculations in Baltic water. Medd. Havsfiskelab. Lysekil. 166

Bakun, A. (1973). Coastal upwelling indices, west coast of North America 1946-71. NOAA Tech. Rep. NMFS SSRF-671

Blanton, J. O., Atkinson, L. P., de Castillejo, F. F., Lavin, A. (1984). Coastal upwelling off the Rías Bajas, Galicia, N. W. Spain: hydrographic studies. Rapp. P.-v. Réun. Cons. int. Explor. Mer 183: 79-90

Blasco, D. (1977). Red tide in the upwelling region of Baja California. Limnol. Oceanogr. 22(2): 255-263

Castro, C. G., Pérez, F. F., Alvarez-Salgado, X. J., Rosón, G., Ríos, A. F. (1994). Hydrographic conditions associated with the relaxation process of an upwelling event off Galician coast (NW Spain). J. geophys. Res. 99: 5135-5147

Chen, Y. Q., Gu, Y. G. (1993). An ecological study of red tides in the East China Sea. In: Smayda, J., Shimizu, Y. (eds.) Toxic phytoplankton blooms in the sea. Elsevier, New York, p. 217-221

Cullen, J. J., Horrigan, S. G., Huntley, M. E., Reid, F. M. H. (1982). Yellow water in La Jolla Bay, California, July 80: a bloom of the dinoflagellate Gymnodinium flavum Kofoid and Sweeney. J, exp. mar. Biol. Ecol. 63: 67-80

Dixon, W. J. (ed.) (1990). BMDP statistical software manual. University of California Press, Berkeley

Estrada, M. (1984). Phytoplankton distribution and composition off the coast of Galicia (North West of Spain). J. Plankton Res. 6(3): 417-434

Figueiras, F. G., Jones, K. J., Mosquera, A. M., AlvarezSalgado, J. A., Edwards, A., Macdougal, N. (1994). Red tide assemblage formation in an estuarine upwelling ecosystem: Ría de Vigo. J. Plankton Res. 16(7): 857-878 
Figueiras, F. G., Niell, F. X. (1987). Composicion del fitoplancton en la Ría de Pontevedra (NO de España). Invest. pesq. 51: $371-409$

Figueiras, F. G., Pazos, Y. (1991). Hydrography and phytoplankton of the Ría de Vigo before and during a red tide of Gymnodinium catenatum Graham. J. Plankton Res. 13(3): 589-608

Figueiras, F. G., Ríos, A. F. (1993). Phytoplankton succession, red tides and hydrographic regime in the Rias Bajas of Galicia. In: Smayda, J., Shimizu, Y. (eds.) Toxic phytoplankton blooms in the sea. Elsevier, New York, p. $239-244$

Figueiras, F. G., Fraga, F. (1990). Vertical nutrient transport during proliferation of Gymnodinium catenatum Graham in Ría de Vigo, Northwest Spain. In: Granéli, E., Sundström, B., Edler, L., Anderson, D. M. (eds.) Toxic marine phytoplankton. Elsevier, New York, p. 144-148

Fiuza, A. F. G. (1983). Upwelling patterns off Portugal. In: Suess, E., Thiede, J. (eds.) Coastal upwelling. Plenum Publishing Corp., New York, p. 85-97

Fraga, F. (1981). Upwelling off the Galician coast North West Spain. In: Richards, F. A. (ed.) Coastal upwelling. American Geophysical Union, Washington, DC, p. 176-182

Fraga, F., Mouriño, C., Manríquez, M. (1982). Las masas de agua en la costa de Galicia: Junio-Octubre. Res. exp. cient. 10: 51-77

Fraga, F., Pérez, F. F., Figueiras, F. G., Ríos, A. F. (1992). Stoichiometric variations of N, P, C, and $\mathrm{O}_{2}$ during a Gymnodinium catenatum red tide and their interpretation. Mar. Ecol. Prog. Ser. 87: 123-134

Fraga, F., Prego, R. (1989). Condiciones hidrográficas previas a la purga de mar. Cuad. Área Ciencias mar., Semin. Estud. Galegos 4: 21-44

Fraga, S., Anderson, D. M., Bravo, I., Reguera, B., Steidinger, K. A., Yentsch, C. M. (1988). Influence of upwelling relaxation on dinoflagellates and shellfish toxicity in the Ría de Vigo, Spain. Estuar. coast. Shelf Sci. 27: 349-361

Fraga, S., Bakun, A. (1993). Global climate change and harmful algal blooms: the example of Gymnodinium catenatum on the Galician coast. In: Smayda, J., Shimizu, Y. (eds.) Toxic phytoplankton blooms in the sea. Elsevier, New York, p. 59-65

Fraga, S., Reguera, B., Bravo, L. (1990). Gymnodinium catenatum bloom formation in the Spanish Rías. In: Graneli, E., Sundström, B., Edler, L., Anderson, D. (eds.) Toxic marine phytoplankton. Elsevier, New York, p. 149-154

Grasshoff, J., Johanssen, H. (1972). A new sensitive and direct method for the automatic determination of ammonia in sea water. J. Cons. int. Explor. Mer 34: 516-521

Hansen, H. P, Grasshoff, K. (1983). Automated chemical analysis. In: Grasshoff, K., Ehrhardt, M., Kremling, K. (eds.) Methods of seawater analysis. Verlag Chemie, Weinheim, p. 347-379

Honjo, T. (1993). Overview on bloom dynamics and physiological ecology of Heterosigma akashivo. In: Smayda, J., Shimizu, Y. (eds.) Toxic phytoplankton blooms in the sea. Elsevier, New York, p. 33-41

Margalef, R. (1956). Estructura y dinámica de la 'purga de mar' en la Ría de Vigo. Invest. pesq. 5: 113-134

Margalef, R., Estrada, M., Blasco, D. (1979). Functional morphology of organisms involved in red tides as adapted to decaying turbulence. In: Taylor, D. L., Seliger, H. H. (eds.) Toxic dinoflagellate blooms. Elsevier North Holland, New York, p. 89-94

McClain, C. R., Chao, S.-Y., Atkinson, L. P., Blanton, J. O., de Castillejo, F. (1986). Wind-driven upwelling in the vicinity of Cape Finisterre, Spain. J. geophys, Res. 91(C4):
$8470-8486$

Moita, M. T. (1993). Development of toxic dinoflagellates in relation to upwelling patterns off Portugal. In: Smayda, J., Shimizu, Y. (eds.) Toxic phytoplankton blooms in the sea. Elsevier, New York, p. 299-304

Mouriño, C., Fraga, F. (1985). Determinacion de nitratos en agua de mar. Invest. pesq. 49:81-96

Pérez, F. F., Alvarez-Salgado, X. A., Roson, G., Ríos, A. F. (1992). Carbonic-calcium system, nutrients and total organic nitrogen in continental runoff to the Galician Rías Baixas, N. W. Spain. Oceanol. Acta 15(6): 595-602

Pingree, R. D., Holligan, P. M., Mardell, G. T., Head, R. N. (1976). Influence of physical stability on spring-summer and autumn phytoplankton blooms in the Celtic Sea. J. mar. biol. Ass. U.K. 56: 845-873

Prego, R. (1992). Flows and budgets of nutrient salts and organic carbon in relation to a red tide in the Ría de Vigo (NW Spain). Mar. Ecol. Prog. Ser. 79: 289-302

Ríos, A. F., Pérez, F. F., Fraga, F. (1992). Water masses in upper and middle North Atlantic ocean east of the Azores high. Deep Sea Res. 39(3/4): 645-658

Smayda, T. J. (1990). Novel and nuisance phytoplankton blooms in the sea: evidence for a global epidemic. In: Granéli, E., Sundström, B., Edler, L., Anderson, D. (eds.) Toxic marine phytoplankton. Elsevier, New York, p. 29-40

Steidinger, K. A. (1983). A re-evaluation of toxic dinoflagellate biology and ecology. In: Round, F. E., Chapman, D. J. (eds.) Progress in phycological research, Vol. 2. Elsevier Science Publishers, New York, p. 147-188

Tenore, K. R., Boyer, L. F., Cal, R. M., Corral, J., García Fernández, C., González, N., González-Gurriaran, E., Hanson, R. B., Iglesias, J., From, M., López-Jamar, E., McClain, J., Pamatmat, M. M., Pérez, A., Rhoads, D. C., Santiago, G. D., Tietjen, J., Westrich, J., Windom, H. L. (1982). Coastal upwelling in the Rías Bajas, N. W. Spain: contrasting the benthic regimes in the Rías of Arosa and Muros. J. mar. Res. 40(3): 701-720

Thomas, W. H., Gibson, C. H. (1990). Quantified small-scale turbulence inhibits a red tide dinoflagellate Gonyaulax polyedra Stein. Deep Sea Res. 37: 1583-1593

Tyler, M. A., Seliger, H. H. (1981). Selection for red tide organisms: physiological responses to the physical environment. Limnol. Oceanogr. 26: 301-324

UNESCO (1981). Tenth report of the joint panel on oceanographic tables and standards. UNESCO Tech. Pap. Mar. Sci. 36

UNESCO (1986). Progress on oceanographic tables and standards 1983-1986: work recommendation of the UNESCO/ SCOR/ICES/IAPSO joint panel. UNESCO Tech. Pap. Mar. Sci. 50

Utermöhl, H. (1958). Zur Vervollkommnung der quantitativen Phytoplankton-Methodik. Mitt. int. Verein. theor. angew. Limnol. 9: 1-38

Varela, M. (1982). Composicion y distribucion del fitoplancton de las Rías de Muros y Arosa y plataforma continental próxima de septiembre de 1978. Bol. Inst. Esp. Oceanogr. 7(2): 191-222

Varela, M. (1992), Upwelling and phytoplankton ecology in Galician (NW Spain) Rias and shelf water. Bol. Inst. Esp. Oceanogr. 8(1): $57-74$

Varela, M., Campos, M. J., Cabanas, J. M., de Castillejo, F. F., Díaz del Río, G. (1987). Composicion y distribucion del fitoplancton en la plataforma de Galicia durante la campaña 'BROEGAN-984' (Septiembre-Octubre de 1984). Bol. Inst. Esp. Oceanogr. 4(1): 95-106

Varela, M., Díaz del Río, G., Alvarez-Ossorio, M. T., Costas, E. (1991). Factors controlling phytoplankton size class distri- 
bution in the upwelling area of the Galician continental shelf (NW Spain). Scientia mar. 55(3): 505-518

Wooster, W., Bakun, A., McClain, D. (1976). The seasonal upwelling cycle along the eastern boundary of the North Atlantic. J. mar. Res. 34(2): 131-141

This article was submitted to the editor
Wyatt, T., Reguera, B. (1989). Historical trends in red tide phenomenon in the Rías Bajas N. W. Spain. In: Okaichi, T., Anderson, D. M., Memoto, T. (eds.) Red tides: biology, environmental science and toxicology. Elsevier, New York, p. 33-36

Manuscript first received: September 29, 1993

Revised version accepted: June 29, 1994 